\title{
Estrogen Receptor $\alpha$ Regulates Dlx3-Mediated Osteoblast Differentiation
}

\author{
Sung Ho Lee ${ }^{1,2}$, Kyo-Nyeo Oh ${ }^{1,2}$, Younho Han', You Hee Choi', and Kwang-Youl Lee ${ }^{1, *}$
}

\begin{abstract}
Estrogen receptor $\alpha(E R-\alpha)$, which is involved in bone metabolism and breast cancer, has been shown to have transcriptional targets. DIx3 is essential for the skeletal development and plays an important role in osteoblast differentiation. Various osteogenic stimulators and transcription factors can induce the protein expression of DIx3. Howev$e r$, the regulatory function of $E R-\alpha$ in the DIx 3 mediated osteogenic process remains unknown. Therefore, we investigated the regulation of DIx3 and found that $E R-\alpha$ is a positive regulator of DIX3 transcription in BMP2-induced osteoblast differentiation. We also found that $E R-\alpha$ interacts with DIx3 and increases its transcriptional activity and DNA binding affinity. Furthermore, we demonstrated that the regulation of DIx3 activity by ER- $\alpha$ is independent of the ligand (estradiol) binding domain. These results indicate that DIx3 is a novel target of $E R-\alpha$, and that $E R-\alpha$ regulates the osteoblast differentiation through modulation of DIx3 expression and/or interaction with DIx3.
\end{abstract}

\section{INTRODUCTION}

The Distal-less (Dlx) family is composed of six members, Dlx1Dlx6, and they have a highly conserved homeobox domain related to that of Distal-less (DII) in Drosophila (Panganiban and Rubenstein, 2002). Dlx2 is essential for craniofacial development and mesenchymal condensation (Robinson and Mahon, 1994). DIx5 and DIx6 play important roles in axial, craniofacial, and appendicular skeletal development (Depew et al., 2002; Robledo et al., 2002). The role of Dlx3 is demonstrated in the development of osteoblasts and chondrocytes from osteogenic cells (Choi et al., 2008; 2009; Ghoul-Mazgar et al., 2005; Hassan et al., 2004).

Estrogen signaling in bone occurs mainly through two estrogen receptors, estrogen receptor alpha (ER- $\alpha)$ and ER- $\beta$. Although both receptors are important in bone physiology and development, a point mutation in ER- $\alpha$ caused unfused growth

\footnotetext{
${ }^{1}$ College of Pharmacy and Research Institute of Drug Development, Chonnam National University, Gwangju 500-757, Korea, ${ }^{2}$ These authors contributed equally to this work.

*Correspondence: kwanglee@chonnam.ac.kr

Received 21 October, 2015; revised 31 October, 2015; accepted 3 November, 2015; published online 15 December, 2015
}

Keywords: Dlx3, estrogen receptor $\alpha$, osteoblast differentiation plates and osteoporosis (Smith et al., 1994). Since then, the role of ER- $\alpha$ on bone metabolism has become a major focus of research (Khosla, 2013; Price et al., 2011; Vico and Vanacker, 2010).

Recent studies suggest that ER- $\alpha$ in osteoblast associates with and regulates the activity of transcription factors or signal transduction pathways (Kousteni et al., 2007; McCarthy et al., 2003; 2011). Hormone-activated ER- $\alpha$ interacts directly with transcription factor Runx2 and increases its transcriptional activity in osteoblast differentiation (McCarthy et al., 2003), whereas ER- $\alpha$ might indirectly modulate the expression and activity of other osteogenic transcription factors as regulators through the regulation of specific components with selected kinase (Kousteni et al., 2007). However, the molecular mechanisms by which ER- $\alpha$ regulates osteoblast differentiation remain to be elucidated.

In this study, we examined the functional role of ER- $\alpha$ in DIx3 modulation. We found that ER- $\alpha$ increases BMP-2-induced osteoblast differentiation. In addition, ER- $\alpha$ interacts with DIx3 and increases the transcriptional activity of Dlx3 in a ligandindependent manner. We also found that ER- $\alpha$ increases the DNA binding affinity of DIx3. Collectively, our results indicate that ER- $\alpha$-induced DIx3 activity may induce the osteoblast differentiation in a ligand independent manner.

\section{MATERIALS AND METHODS}

\section{Materials}

Estradiol (E2) was purchased from Sigma-Aldrich. Antibodies against the following epitopes were used: Myc (9E10) and HA (12CA5) from Roche Applied Science (Germany), GFP (G1544) from Santa Cruz Biotechnology (USA), and $\alpha$-Tubulin (B-5-1-2) from Sigma-Aldrich (USA).

\section{Cell culture}

C2C12 mouse myoblast cells and HEK293 cells were maintained in DMEM containing $10 \%$ heat-inactivated FBS and antibiotic-antimycotic solution at $37^{\circ} \mathrm{C}$ in a humidified atmosphere of $5 \% \mathrm{CO}_{2}$. DMEM, FBS, and antibiotic-antimycotic solution were purchased from Life Technologies (USA).

\section{Plasmids and transfection}

The N-terminal epitope-tagged human DIx3 expression plasmids were constructed in a CMV promoter-derived mammalian expression vector (pCS4). The HA-tagged full length-ER- $\alpha$ and ER- $\alpha-\Delta$ LBD were kindly provided by Dr. Keesook Lee (Chonnam National University, Korea). The polyethyleneimine (PEI) 
(Polysciences Inc., USA)-mediated method was used for transient transfection. Total amounts of transfected plasmids in each condition were equalized with an empty vector.

\section{Immunoblotting (IB) and immunoprecipitation (IP)}

HEK293 cells were co-transfected with the indicated plasmids and then lysed with an ice cold lysis buffer previously described (Lee et al., 2013). After centrifugation, supernatants containing $30 \mu \mathrm{g}$ of total protein were subjected to SDS-PAGE. The separated proteins were transferred to a polyvinylidene fluoride membrane for $120 \mathrm{~min}$ at $70 \mathrm{~V}$. After exposure for $1 \mathrm{~h}$ to TBST containing $0.05 \%$ Tween 20 and $5 \%$ dried nonfat milk, the membranes were incubated with the appropriate primary antibodies for overnight at $4^{\circ} \mathrm{C}$, and then with HRP-conjugated secondary antibodies for $1 \mathrm{~h}$ at room temperature. The proteins were visualized using ECL reagent (Millipore Corporation). For IP, centrifuged lysate supernatants were precipitated using appropriate antibodies and Protein A-conjugated Sepharose beads. The immunoprecipitated proteins were resolved using SDS-PAGE and visualized using IB.

\section{Semi-quantitative RT-PCR}

Total RNA was extracted from $\mathrm{C} 2 \mathrm{C} 12$ cells with the use of RNAiso Plus (Takara Bio Inc., Japan) according to the manufacturer's instructions. Random-primed cDNAs were synthesized from $1 \mu \mathrm{g}$ of total RNA by using the GoScript Reverse Transcription System (Promega, USA). The following conditions were used for PCR: initial denaturation at $94^{\circ} \mathrm{C}$ for $5 \mathrm{~min}$, 25-30 cycles of denaturation at $94^{\circ} \mathrm{C}$ for $1 \mathrm{~min}$, annealing at a temperature optimized for each primer pair for $1 \mathrm{~min}$, extension at $72^{\circ} \mathrm{C}$ for $1 \mathrm{~min}$, and a final extension at $72^{\circ} \mathrm{C}$ for $10 \mathrm{~min}$. The primer sequences used are as follows: mouse Bone sialoprotein (BSP) forward 5'-ACA CTT ACC GAG CTT ATG AGG-3' and reverse 5'-TTG CGC AGT TAG CAA TAG CAC-3' (Jeong et al., 2010); mouse Collagen type I $\alpha 1$ (COL1A1) forward 5'TCT CCA CTC TTC TAG GTT CCT-3' and reverse 5'-TTG GGT CAT TTC CAC ATG C-3' (Choi et al., 2012; Dao et al.,
2011) ; mouse Glyceraldehyde 3-phosphate dehydrogenase (GAPDH) forward 5'-ACC ACA GTC CAT GCC ATC AC-3' and reverse 5'-TCC ACC ACC CTG TTG CTG TA-3' (Dao et al., 2011).

\section{Luciferase reporter assay}

Luciferase reporter assays were conducted using alkaline phosphatase (ALP) promoter reporter, BSP promoter reporter, Dlx-response element (DRE) reporter, and estrogen-response element (ERE) reporter plasmids. HEK293 cells were transfected with the indicated plasmids and reporter plasmids, and pCMV- $\beta$-gal for $36 \mathrm{~h}$. All the luciferase assays were performed using a Luciferase Reporter Assay Kit (Promega). Data were normalized by corresponding $\beta$-galactosidase activity to compensate for transfection efficiency.

\section{ALP staining}

$\mathrm{C} 2 \mathrm{C} 12$ cells were transfected and then stimulated with BMP2 $(10 \mathrm{ng} / \mathrm{ml})$ for 3 days. Cells were fixed with $4 \%$ paraformaldehyde (Sigma-Aldrich) for $10 \mathrm{~min}$ and stained with $300 \mu \mathrm{g} / \mathrm{ml}$ BCIP/NBT solution (Sigma-Aldrich) for $15 \mathrm{~min}$ at room temperature. ALP-positive cells were stained a blue/purple color.

\section{DNA affinity precipitation assay (DAPA)}

The DNA binding assay was performed by mixing whole cell lysates with a biotinylated oligomers containing three tandem repeats of the DIx3-responsive element, and the DNA-protein complexes were precipitated using streptavidin-coated beads. The binding proteins were eluted using loading buffer and resolved using $12 \%$ SDS-PAGE followed by IB. The following biotinylated DRE sequences were used: DRE forward 5'-biotinGCG ATA ATT GCG GCG ATA ATT GCG GCG ATA ATT GCG$3^{\prime}$ and reverse 5'-biotin-CGC AAT TAT CGC CGC AAT TAT CGC CGC AAT TAT CGC-3' (Li et al., 2014).

\section{Statistical analysis}

The data are representative of three independent experiments.
$\boldsymbol{A}$

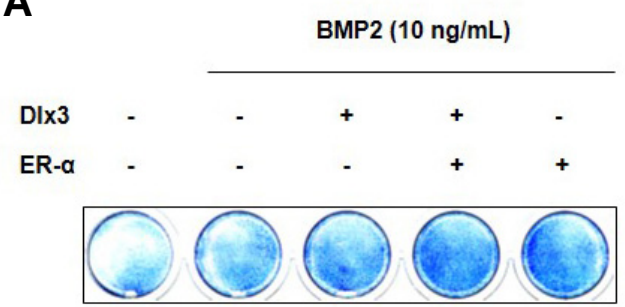

B

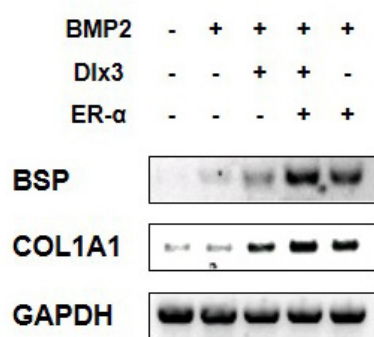

C

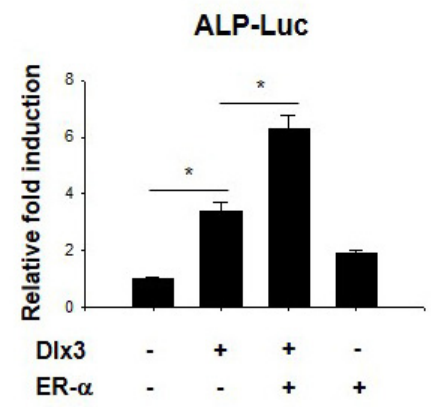

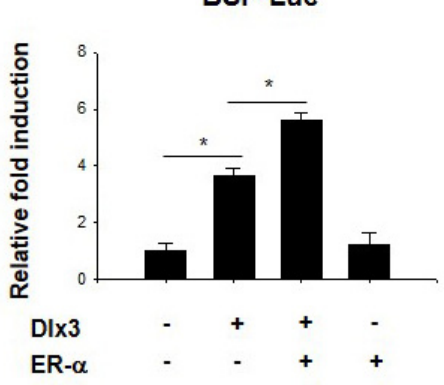

Fig. 1. ER- $\alpha$ induces Dlx3-enhanced osteoblast differentiation. (A) $\mathrm{C} 2 \mathrm{C} 12$ cells were transfected with an empty vector or the indicated combinations of DIX3 and ER- $\alpha$, stimulated with BMP2, and then stained for ALP activity. (B) C2C12 cells were transfected with an empty vector or the indicated combinations of Dlx3 and ER- $\alpha$, stimulated with BMP2, and then harvested for RT-PCR. GAPDH is the loading control. (C) $\mathrm{C} 2 \mathrm{C} 12$ cells were transfected with $\mathrm{pCMV}-\beta$ gal, ALP-Luc, or BSP-Luc reporter vector along with the indicated combinations of DIx3 and ER- $\alpha$. Luciferase activity was then measured after $36 \mathrm{~h}$. Data are expressed as means \pm SEM of at least three experiments. ${ }^{*} p<0.05$ by Student's $t$-test. 
Sung Ho Lee et al.

ER- $\alpha$ Regulated DIx3-Mediated Osteogenesis

$\boldsymbol{A}$
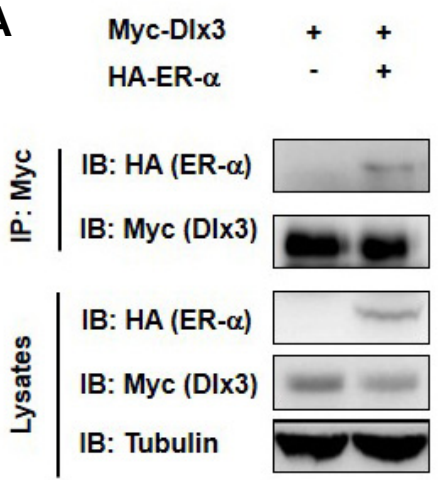

C

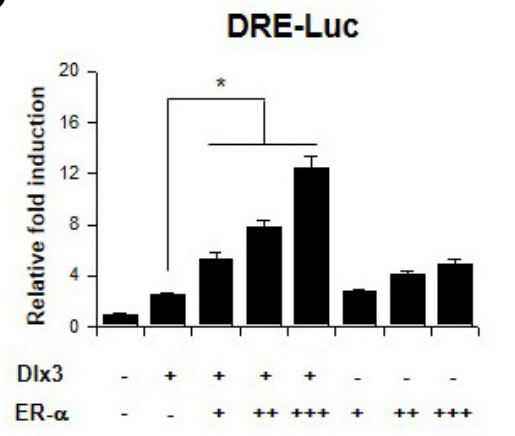

$\boldsymbol{B}$
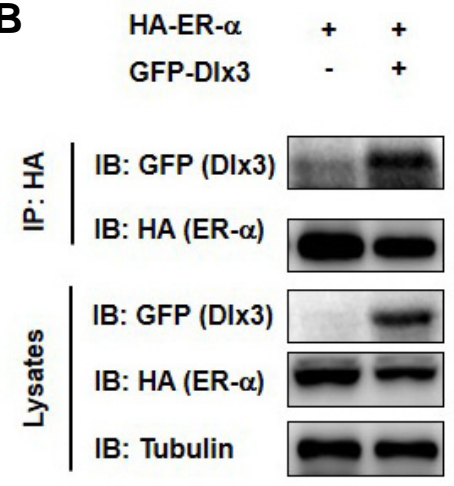

$\boldsymbol{D}$

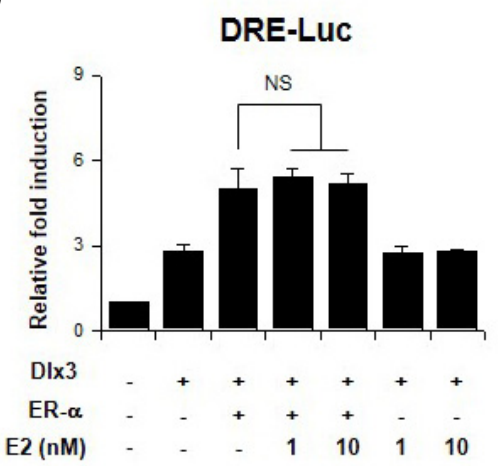

$E$

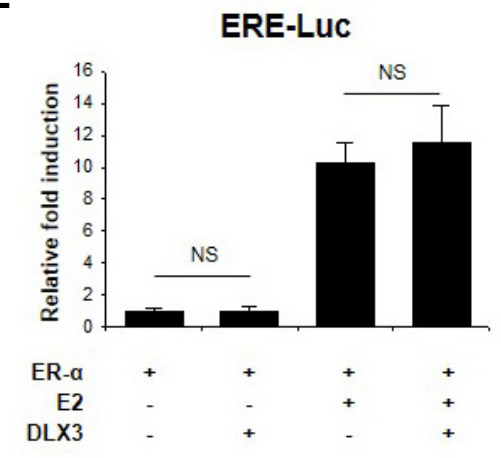

Fig. 2. ER- $\alpha$ physically associates with and induces the transcriptional activity of Dlx3. HEK293 cells were transfected with Myc-tagged DIx3 and HA-tagged ER- $\alpha$ (A) or with HA-tagged ER- $\alpha$ and GFP-tagged Dlx3 (B), and the cell lysates were subjected to immunoprecipitation using an anti-Myc antibody and Protein A-Sepharose beads. The immunoprecipitated proteins were then analyzed using immunoblotting. (C) HEK293 cells were transfected with pCMV- $\beta$-gal and a DRE-Luc reporter vector along with the indicated combinations of DIx3 and ER- $\alpha$. Luciferase activity was then measured after $36 \mathrm{~h}$. Data are expressed as means \pm SEM of at least three experiments. ${ }^{*} p<0.05$ by Student's $t-$ test. (D and E) HEK293 cells were transfected with pCMV- $\beta$-gal, DRE-Luc (D), or ERE-Luc (E) reporter vectors along with the indicated combinations of Dlx3 and ER- $\alpha$. Transfected cells were treated for $12 \mathrm{~h}$ with estradiol (E2) and luciferase activity was then measured. Data are expressed as means \pm SEM of at least three experiments. NS, not significant by Student's $t$-test.

The Results are expressed as means \pm standard error of the mean. Analyses were performed with Student's $t$-test. $P$-values of less than 0.05 were considered significant.

\section{RESULTS}

\section{ER- $\alpha$ affects DIx3 in BMP2-stimulated osteoblast \\ differentiation}

First, we examined the effect of ER- $\alpha$ on DIx3-driven induction of osteoblast differentiation. $\mathrm{C} 2 \mathrm{C} 12$ cells were transfected with DIx3 and ER- $\alpha$ and then treated with BMP2. ALP staining showed that ER- $\alpha$ increases Dlx3-induced activation of osteoblast differentiation (Fig. 1A). Next, we examined whether ER- $\alpha$ affects the expression of osteogenic marker genes. ER- $\alpha$ increased the expression of BSP, and COL1A1 and cotransfection of Dlx3 and ER- $\alpha$ further increased their expression (Fig. 1B). We also examined the effects of ER- $\alpha$ on the transcriptional activities of Dlx3-induced activation of ALP and BSP promoter reporter genes. C2C12 cells were transfected with ALP-Luc and BSP-Luc along with combinations of DIx3 and ER- $\alpha$. DIx3 alone increased the ALP-Luc and BSP-Luc activity, which was further enhanced by ER- $\alpha$ (Fig. 1C). Collec- tively, these results indicate that ER- $\alpha$ plays a positive role in osteoblast differentiation and reinforces the Dlx3-induced activation of osteoblast differentiation.

\section{$E R-\alpha$ physically associates with and induces the transcriptional activity of DIx3}

To determine whether a physical interaction between DIx3 and ER- $\alpha$ affected BMP2-induced osteoblast differentiation, HEK293 cells were transfected with Myc-DIx3 and HA-ER- $\alpha$, followed by IP and IB. Additionally, HEK293 cells were transfected with HA-ER- $\alpha$ and GFP-DIx3 and then analyzed using IP and IB. These experiments showed that DIx3 was bound to ER$\alpha$ (Figs. 2A and 2B). To determine whether ER- $\alpha$ can regulate the transcriptional activity of DIX3, HEK293 cells were transfected with a DRE-Luc reporter gene with different combinations of DIx3 and ER- $\alpha$. DIx3 by itself increased reporter activity compared to control group, and co-transfection with ER- $\alpha$ further increased reporter activity in a dose-dependent manner (Fig. 2C). To determine whether its regulation is related to the ligand, we treated the cells with E2. However, the transcriptional activity of DIx3 was not influenced by E2 (Fig. 2D). Since the nature of the interactions between DIx 3 and ER- $\alpha$ predicted 
$\boldsymbol{A}$

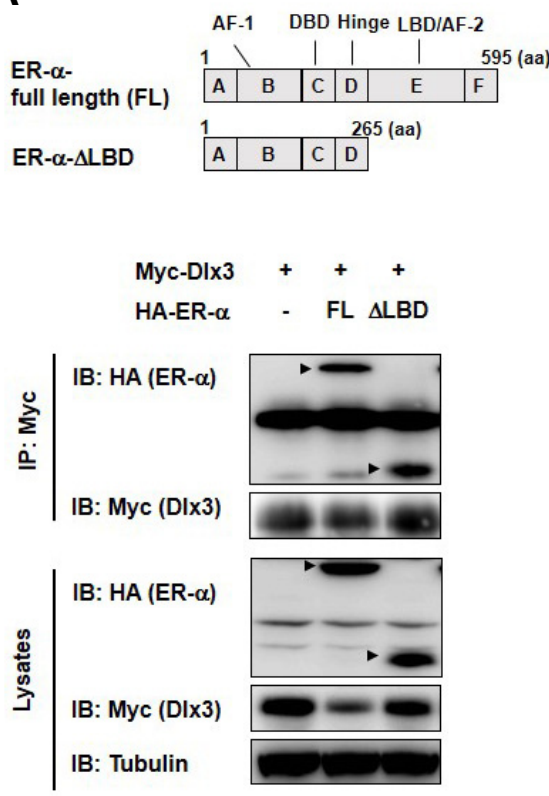

B
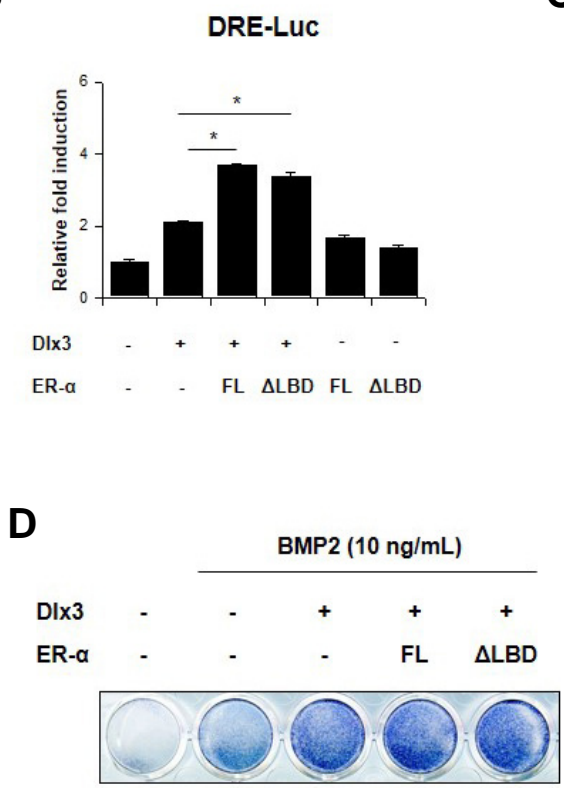

C

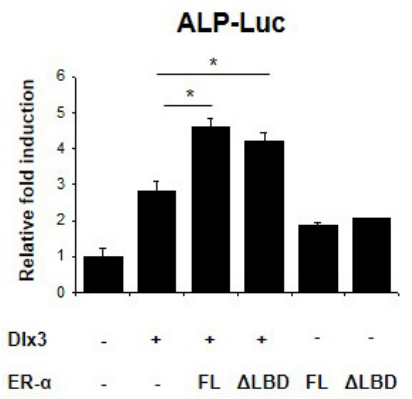

Fig. 3. ER- $\alpha-\Delta L B D$ interacts with and affects Dlx3 in BMP2-stimulated osteoblast differentiation. (A) A schematic of the ER- $\alpha$ structure. FL, full length; AF-1, activation function 1; DBD, DNA binding domain; LBD, ligand binding domain; AF-2, activation function 2 . HEK293 cells were transfected with the indicated combinations of plasmids and $48 \mathrm{~h}$ later cell lysates were harvested and analyzed using immunoprecipitation and immunoblotting. (B) HEK293 cells were transfected with pCMV- $\beta$-gal, and DRE-Luc reporter vector along with the indicated combinations of DIx3, ER- $\alpha-F L$ or ER- $\alpha-\Delta$ LBD. Luciferase activity was measured after $36 \mathrm{~h}$. Data are expressed as mean \pm SEM of at least three experiments. ${ }^{*} p<0.05$ by Student $t$-test. (C) C2C12 cells were transfected with pCMV- $\beta$-gal, ALP-Luc reporter vector along with the indicated combinations of DIx3, ER- $\alpha-F L$ or ER- $\alpha-\Delta$ LBD. Luciferase activity was measured after $36 \mathrm{~h}$. Data are expressed as mean \pm SEM of at least three experiments. ${ }^{*} p<0.05$ by Student's $t$-test. (D) $\mathrm{C} 2 \mathrm{C} 12$ cells were transfected with an empty vector or the indicated combinations of Dlx3 and ER- $\alpha-F L$ or ER- $\alpha-\triangle L B D$, stimulated with BMP2, and then stained for ALP activity.

that they might also regulate each other, next we examined whether DIx3 can affect ER-transcriptional activity. HEK293 cells were transfected an ERE-Luc with different combinations of DIx3 and ER- $\alpha$ and then treated with E2 for $12 \mathrm{~h}$. We found that DIx3 had no effect on ER- $\alpha$-dependent reporter gene activity (Fig. 2E). These results suggest that ER- $\alpha$ interacts with Dlx3 and increases its transcriptional activity.

\section{$E R-\alpha-\triangle L B D$ interacts with and affects $D / \times 3$ in BMP2-stimulated osteoblast differentiation}

To determine whether the regulation of DIx3 by ER- $\alpha$ is independent of the ligand (E2), we fragmented ER- $\alpha$ based on the characteristics in the previous report (Kumar et al., 1987). In particular, we used ER- $\alpha-F L$ and the A/B/C/D fragment (ER- $\alpha-$ $\triangle$ LBD). HEK293 cells were transfected with Myc-Dlx3 and HAER- $\alpha-F L$ or HA-ER- $\alpha-\Delta$ LBD and analyzed using IP and IB. We found that DIx3 was bound to both HA-ER- $\alpha-F L$ and HA-ER- $\alpha-$ $\triangle$ LBD (Fig. 3A). Next, we examined whether HA-ER- $\alpha-\Delta$ LBD also can modulate the transcriptional activity of DIx3. HEK293 cells were transfected with a DRE-Luc reporter gene along with combinations of DIx3 and ER- $\alpha-F L$ or ER- $\alpha-\Delta$ LBD. We found that $E R-\alpha-\Delta L B D$ also increased the transcriptional activity of DIx3 (Fig. 3B). Then we examined whether HA-ER- $\alpha-\Delta$ LBD affects BMP2-induced osteoblast differentiation. We found that HA-ER- $\alpha-\Delta$ LBD enhanced ALP-Luc activity (Fig. $3 C$ ) and ALP staining (Fig. 3D). These results indicate that the regulation of DIx3 by ER- $\alpha$ is independent of the ligand (E2), and that un- liganded ER- $\alpha$ interacts with DIx3 and enhances BMP2induced osteoblast differentiation.

\section{$E R-\alpha$ increases DNA affinity binding of DIx3 in a ligand-independent manner}

As ER- $\alpha$ interacts with Dlx3, we examined whether ER- $\alpha$ has an effect on Dlx3 binding to DRE in experiments using a DAPA assay, in which short biotinylated DNA probes containing the DRE sequences were hybridized with nuclear proteins obtained from HEK293 cells transfected with combinations of Dlx3 and ER- $\alpha-F L$ or ER- $\alpha-\Delta$ LBD. We found that both ER- $\alpha-F L$ and ER$\alpha-\Delta \mathrm{LBD}$ induced efficient Dlx3 association with the DRE motif (Figs. 4A and 4B). These results imply that ER- $\alpha$ increases the affinity of DIx3 for the DRE sequence in a ligand-independent manner.

\section{DISCUSSION}

Estrogen is an important hormone for bone development, growth, and metabolism. Although many studies have focused on estrogen as an inhibitor of bone resorption, others suggest additional effects on bone formation. Estrogen may act in part on osteoblasts to inhibit apoptosis (Gohel et al., 1999; Kousteni et al., 2001; 2002; Zhou et al., 2001) or to regulate AP-1-related transcription factors by specific kinase-dependent pathways (Chen et al., 1996; Kelly and Levin, 2001; Kousteni et al., 2002; Zhou et al., 2001) Interactions have been reported between 
Sung Ho Lee et al.

ER- $\alpha$ Regulated DIx3-Mediated Osteogenesis

$\boldsymbol{A}$

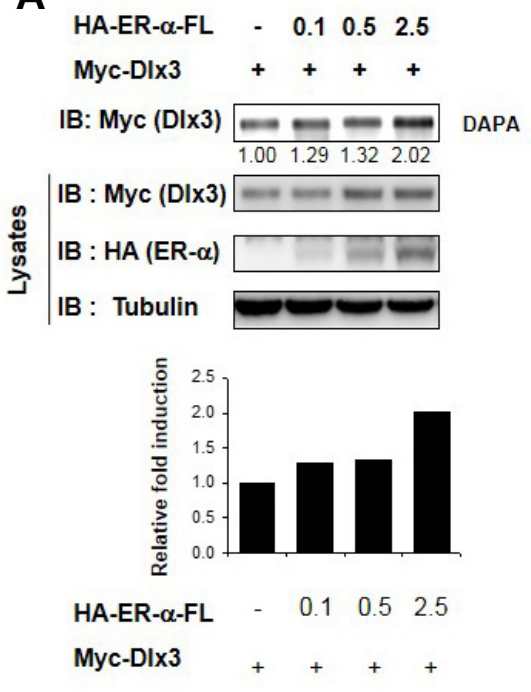

B

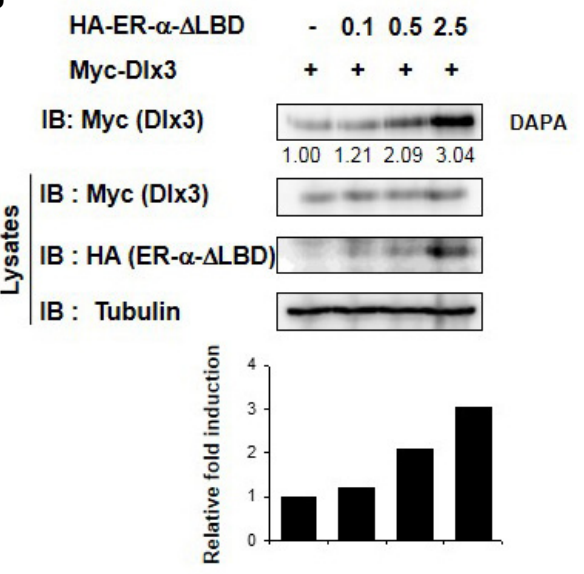

HA-ER- $\alpha$ - $\Delta$ LBD $\quad-\quad 0.1 \quad 0.5 \quad 2.5$
Fig. 4. ER- $\alpha$ increases DNA binding affinity of Dlx3 in a ligandindependent manner. (A, B) HEK293 cells were transfected with an empty vector or indicated combinations of DIX3 and ER- $\alpha$ $\mathrm{FL}(\mathrm{A})$ or ER- $\alpha-\Delta \mathrm{LBD}(\mathrm{B})$. The cell lysates were incubated with biotinlabeled oligonucleotide Dlx3responsive elements, and the DNA-bound proteins were analyzed by immunoblotting using an anti-DIx3 antibody.
ER- $\alpha$ and several other transcription factors, including retinoid receptors (Lee et al., 1998), forkhead transcription factors (Schuur et al., 2001), Smads (Matsuda et al., 2001; Yamamoto et al., 2002), Stat5 (Bjornstrom and Sjoberg, 2002), GATA4 (Guemes et al., 2014), AP-1 (Lambertini et al., 2008), C/EBP $\delta$ (Chang et al., 2005), and Runx2 (Lambertini et al., 2007; McCarthy et al., 2003). However, the regulatory mechanism of estrogen and the ER in osteoblasts remains to be elucidated. In this study, we examined the effect of estrogen and ER- $\alpha$ on Dlx3 (Hassan et al., 2004; Robinson and Mahon, 1994).

Recent studies show that unliganded ER- $\alpha$ regulates various cell signaling and the expressions of target genes. Unliganded ER- $\alpha$ is required for the osteogenic response to mechanical loading in a ligand-independent manner (Windahl et al., 2013). Sirtuin 1 represses estrogen-signaling, ligand-independent ER$\alpha$-mediated transcription, and cell proliferation in estrogenresponsive breast cells (Moore and Faller, 2013). Unliganded ER- $\alpha$ promotes PC12 cell survival during serum starvation (Ferriere et al., 2013). Unliganded ER stimulates BSP gene expression (Takai et al., 2014). In our study, we found that ER- $\alpha$ overexpression induced DIx3-transcriptional activities (Fig. 2C), whereas the activities were not influenced by E2 (Fig. 2D). These results suggest that unliganded ER- $\alpha$ is required for the regulation of DIx3.

The internal structure of the ER contains six distinct regions which are labeled $A$ through $F$ as shown in Fig. $3 A$. The $N-$ terminal region $(A / B)$ contains activation function 1 (AF-1) which is responsible for constitutive ligand-independent activation of the receptor (Weigel, 1996). Previous study revealed that $A / B$ region of the ER especially on serine/threonine residue can be phosphorylated by mitogen-activated protein kinase (Kato et al. 1995). The C domain is a DNA-binding domain (DBD) that binds to specific sequences of DNA called hormone response elements (HRE), or in this case, EREs (Schwabe et al., 1993). The LBD located in the E region of ERs attributes to liganddependent activation of the receptor, in turn it induces the transcriptional activity by the action of AF-2 located at the Cterminal portion of the $E$ region (Wurtz et al., 1996; 1998). As we found that unliganded ER- $\alpha$ regulates DIx3 function (Fig. 2), we hypothesized that AF-1 might be sufficient for regulation of DIx3 by ER- $\alpha$ but not AF-2. As expected, we found that ER- $\alpha-$ $\triangle \mathrm{LBD}$ interacts with Dlx3 and regulates its transcriptional activity (Figs. $3 A$ and $3 B$ ) by increasing its DNA binding affinity (Fig. $4 B$ ). The interaction between ER- $\alpha$ and Runx 2 or Stat5 maps to the ER- $\alpha$ DBD (Bjornstrom and Sjoberg, 2002; McCarthy et al., 2003). We expect that ER- $\alpha$ and DIx3 interact through the DBD of ER- $\alpha$, although we cannot rule out other sites that may be involved in this interaction. Further study of this interaction will enhance our understanding of the regulatory mechanisms of ER- $\alpha$ function and the regulation of DIx3 in osteoblast differentiation. Therefore, determination of the interaction site(s) to understand the significance of such regulation between DIx3
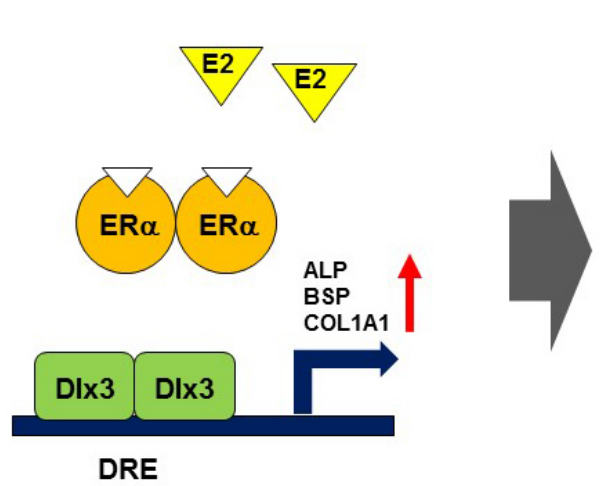

Fig. 5. The proposed model for regulation of DIx3 by ER- $\alpha$. DIx3 binds to DRE site on osteogenic genes such as ALP, BSP, COL1A1 and subsequently increases their activities. ER- $\alpha$ interacts and consequently reinforces DIx3mediated regulation in a ligand independent manner. 
and ER- $\alpha$ is needed.

In conclusion, as shown in Fig. 5, we have found that unliganded ER- $\alpha$ physically interacts with DIx3 in vivo and functions as a coactivator in regulating Dlx3-mediated signaling in osteoblast differentiation. These findings may provide insight into the understanding of ER- $\alpha$ function in osteoblast differentiation.

\section{ACKNOWLEDGMENTS}

This work was supported by grants to KYL from the National Research Foundation of Korea (NRF) funded by the Korean government (MSIP; NRF-2013R1A2A2A07067609).

\section{REFERENCES}

Bjornstrom, L., and Sjoberg, M. (2002). Mutations in the estrogen receptor DNA-binding domain discriminate between the classical mechanism of action and cross-talk with Stat5b and activating protein 1 (AP-1). J. Biol. Chem. 277, 48479-48483.

Chang, W., Parra, M., Centrella, M., and McCarthy, T.L. (2005). Interactions between CCAAT enhancer binding protein delta and estrogen receptor alpha control insulin-like growth factor I (igf1) and estrogen receptor-dependent gene expression in osteoblasts. Gene 345, 225-235.

Chen, T.K., Smith, L.M., Gebhardt, D.K., Birrer, M.J., and Brown, P.H. (1996). Activation and inhibition of the AP-1 complex in human breast cancer cells. Mol. Carcinog. 15, 215-226.

Choi, S.J., Song, I.S., Ryu, O.H., Choi, S.W., Hart, P.S., Wu, W.W., Shen, R.F., and Hart, T.C. (2008). A 4 bp deletion mutation in DLX3 enhances osteoblastic differentiation and bone formation in vitro. Bone 42, 162-171.

Choi, S.J., Roodman, G.D., Feng, J.Q., Song, I.S., Amin, K., Hart, P.S., Wright, J.T., Haruyama, N., and Hart, T.C. (2009). In vivo impact of a $4 \mathrm{bp}$ deletion mutation in the DLX3 gene on bone development. Dev. Biol. 325, 129-137.

Choi, Y.H., Choi, H.J., Lee, K.Y., and Oh, J.W. (2012). Akt1 regulates phosphorylation and osteogenic activity of Dlx3. Biochem. Biophys. Res. Commun. 425, 800-805.

Dao, T.T., Lee, K.Y., Jeong, H.M., Nguyen, P.H., Tran, T.L., Thuong, P.T., Nguyen, B.T., and Oh, W.K. (2011). ent-Kaurane diterpenoids from Croton tonkinensis stimulate osteoblast differentiation. J. Nat. Prod. 74, 2526-2531.

Depew, M.J., Lufkin, T., and Rubenstein, J.L. (2002). Specification of jaw subdivisions by Dlx genes. Science 298, 381-385.

Ferriere, F., Habauzit, D., Pakdel, F., Saligaut, C., and Flouriot, G. (2013). Unliganded estrogen receptor alpha promotes PC12 survival during serum starvation. PLoS One 8, e69081.

Ghoul-Mazgar, S., Hotton, D., Lezot, F., Blin-Wakkach, C., Asselin, A., Sautier, J.M., and Berdal, A. (2005). Expression pattern of Dlx3 during cell differentiation in mineralized tissues. Bone 37, 799-809.

Gohel, A., McCarthy, M.B., and Gronowicz, G. (1999). Estrogen prevents glucocorticoid-induced apoptosis in osteoblasts in vivo and in vitro. Endocrinology 140, 5339-5347.

Guemes, M., Garcia, A.J., Rigueur, D., Runke, S., Wang, W., Zhao, G., Mayorga, V.H., Atti, E., Tetradis, S., Peault, B., et al. (2014). GATA4 is essential for bone mineralization via ERalpha and TGFbeta/BMP pathways. J. Bone Miner. Res. 29, 2676-2687.

Hassan, M.Q., Javed, A., Morasso, M.I., Karlin, J., Montecino, M., van Wijnen, A.J., Stein, G.S., Stein, J.L., and Lian, J.B. (2004). Dlx3 transcriptional regulation of osteoblast differentiation: temporal recruitment of Msx2, DIx3, and DIx5 homeodomain proteins to chromatin of the osteocalcin gene. Mol. Cell Biol. 24, 9248-9261.

Jeong, H.M., Han, E.H., Jin, Y.H., Hwang, Y.P., Kim, H.G., Park, B.H., Kim, J.Y., Chung, Y.C., Lee, K.Y., and Jeong, H.G. (2010). Saponins from the roots of Platycodon grandiflorum stimulate osteoblast differentiation via p38 MAPK- and ERK-dependent RUNX2 activation. Food Chem. Toxicol. 48, 3362-3368.

Kato, S., Endoh, H., Masuhiro, Y., Kitamoto, T., Uchiyama, S., Sasaki, H., Masushige, S., Gotoh, Y., Nishida, E., Kawashima,

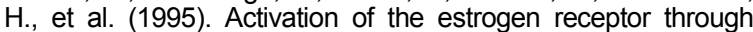
phosphorylation by mitogen-activated protein kinase. Science
270, 1491-1494.

Kelly, M.J., and Levin, E.R. (2001). Rapid actions of plasma membrane estrogen receptors. Trends Endocrinol. Metab. 12, 152-156.

Khosla, S. (2013). Pathogenesis of age-related bone loss in humans. J. Gerontol. A Biol. Sci. Med. Sci. 68, 1226-1235.

Kousteni, S., Bellido, T., Plotkin, L.I., O'Brien, C.A., Bodenner, D.L., Han, L., Han, K., DiGregorio, G.B., Katzenellenbogen, J.A., Katzenellenbogen, B.S., et al. (2001). Nongenotropic, sexnonspecific signaling through the estrogen or androgen receptors: dissociation from transcriptional activity. Cell 104, 719-730.

Kousteni, S., Chen, J.R., Bellido, T., Han, L., Ali, A.A., O'Brien, C.A., Plotkin, L., Fu, Q., Mancino, A.T., Wen, Y., et al. (2002). Reversal of bone loss in mice by nongenotropic signaling of sex steroids. Science 298, 843-846.

Kousteni, S., Almeida, M., Han, L., Bellido, T., Jilka, R.L., and Manolagas, S.C. (2007). Induction of osteoblast differentiation by selective activation of kinase-mediated actions of the estrogen receptor. Mol. Cell Biol. 27, 1516-1530.

Kumar, V., Green, S., Stack, G., Berry, M., Jin, J.R., and Chambon, P. (1987). Functional domains of the human estrogen receptor. Cell 51, 941-951.

Lambertini, E., Penolazzi, L., Tavanti, E., Schincaglia, G.P., Zennaro, M., Gambari, R., and Piva, R. (2007). Human estrogen receptor alpha gene is a target of Runx2 transcription factor in osteoblasts. Exp. Cell Res. 313, 1548-1560.

Lambertini, E., Tavanti, E., Torreggiani, E., Penolazzi, L., Gambari, R., and Piva, R. (2008). ERalpha and AP-1 interact in vivo with a specific sequence of the $F$ promoter of the human ERalpha gene in osteoblasts. J. Cell Physiol. 216, 101-110.

Lee, S.K., Choi, H.S., Song, M.R., Lee, M.O., and Lee, J.W. (1998). Estrogen receptor, a common interaction partner for a subset of nuclear receptors. Mol. Endocrinol. 12, 1184-1192.

Lee, S.H., Choi, Y.H., Kim, Y.J., Choi, H.S., Yeo, C.Y., and Lee, K.Y (2013). Prolyl isomerase Pin1 enhances osteoblast differentiation through Runx2 regulation. FEBS Lett. 587, 36403647.

Li, H., Jeong, H.M., Choi, Y.H., Kim, J.H., Choi, J.K., Yeo, C.Y., Jeong, H.G., Jeong, T.C., Chun, C., and Lee, K.Y. (2014) Protein kinase a phosphorylates DIx3 and regulates the function of Dlx3 during osteoblast differentiation. J. Cell. Biochem. 115, 2004-2011.

Matsuda, T., Yamamoto, T., Muraguchi, A., and Saatcioglu, F. (2001). Cross-talk between transforming growth factor-beta and estrogen receptor signaling through Smad3. J. Biol. Chem. 276, 42908-42914.

McCarthy, T.L., Chang, W.Z., Liu, Y., and Centrella, M. (2003). Runx2 integrates estrogen activity in osteoblasts. J. Biol. Chem. 278, 43121-43129.

McCarthy, T.L., Kallen, C.B., and Centrella, M. (2011). beta-Catenin independent cross-control between the estradiol and Wnt pathways in osteoblasts. Gene 479, 16-28.

Moore, R.L., and Faller, D.V. (2013). SIRT1 represses estrogensignaling, ligand-independent ERalpha-mediated transcription, and cell proliferation in estrogen-responsive breast cells. J. Endocrinol. 216, 273-285.

Panganiban, G., and Rubenstein, J.L. (2002) Developmental functions of the Distal-less/DIx homeobox genes. Development $129,4371-4386$

Price, J.S., Sugiyama, T., Galea, G.L., Meakin, L.B., Sunters, A., and Lanyon, L.E. (2011). Role of endocrine and paracrine factors in the adaptation of bone to mechanical loading. Curr. Osteoporos. Rep. 9, 76-82.

Robinson, G.W., and Mahon, K.A. (1994). Differential and overlapping expression domains of Dlx-2 and Dlx-3 suggest distinct roles for Distal-less homeobox genes in craniofacial development. Mech. Dev. 48, 199-215.

Robledo, R.F., Rajan, L., Li, X., and Lufkin, T. (2002). The Dlx5 and DIx6 homeobox genes are essential for craniofacial, axial, and appendicular skeletal development. Genes Dev. 16, 1089-1101.

Schuur, E.R., Loktev, A.V., Sharma, M., Sun, Z., Roth, R.A., and Weigel, R.J. (2001). Ligand-dependent interaction of estrogen receptor-alpha with members of the forkhead transcription factor family. J. Biol. Chem. 276, 33554-33560.

Schwabe, J.W., Chapman, L., Finch, J.T., Rhodes, D., and 
Neuhaus, D. (1993). DNA recognition by the oestrogen receptor: from solution to the crystal. Structure 1, 187-204.

Smith, E.P., Boyd, J., Frank, G.R., Takahashi, H., Cohen, R.M Specker, B., Williams, T.C., Lubahn, D.B., and Korach, K.S. (1994). Estrogen resistance caused by a mutation in the estrogen-receptor gene in a man. N. Engl. J. Med. 331, 10561061.

Takai, H., Matsumura, H., Matsui, S., Kim, K.M., Mezawa, M., Nakayama, Y., and Ogata, Y. (2014). Unliganded estrogen receptor alpha stimulates bone sialoprotein gene expression. Gene 539, 50-57.

Vico, L., and Vanacker, J.M. (2010). Sex hormones and their receptors in bone homeostasis: insights from genetically modified mouse models. Osteoporos Int. 21, 365-372.

Weigel, N.L. (1996). Steroid hormone receptors and their regulation by phosphorylation. Biochem. J. 319 (Pt 3), 657-667.

Windahl, S.H., Saxon, L., Borjesson, A.E., Lagerquist, M.K., Frenkel, B., Henning, P., Lerner, U.H., Galea, G.L., Meakin, L.B., Engdahl, C., et al. (2013). Estrogen receptor-alpha is required for the osteogenic response to mechanical loading in a ligand- independent manner involving its activation function 1 but not 2 . J. Bone Miner Res. 28, 291-301.

Wurtz, J.M., Bourguet, W., Renaud, J.P., Vivat, V., Chambon, P. Moras, D., and Gronemeyer, H. (1996). A canonical structure for the ligand-binding domain of nuclear receptors. Nat. Struct. Biol. 3, 87-94.

Wurtz, J.M., Egner, U., Heinrich, N., Moras, D., and MuellerFahrnow, A. (1998). Three-dimensional models of estrogen receptor ligand binding domain complexes, based on related crystal structures and mutational and structure-activity relationship data. J. Med. Chem. 41, 1803-1814.

Yamamoto, T., Saatcioglu, F., and Matsuda, T. (2002). Cross-talk between bone morphogenic proteins and estrogen receptor signaling. Endocrinology 143, 2635-2642.

Zhou, S., Zilberman, Y., Wassermann, K., Bain, S.D., Sadovsky, Y., and Gazit, D. (2001). Estrogen modulates estrogen recepto alpha and beta expression, osteogenic activity, and apoptosis in mesenchymal stem cells (MSCs) of osteoporotic mice. J. Cell Biochem. Suppl. 36, 144-155. 